\title{
ОСНОВНІ НАПРЯМИ ПРИКЛАДНОЇ КІРЛІАНОГРАФІЇ В ЕКОЛОГІЇ ТА МЕДИЦИНІ
}

\author{
О. П. Мінцер, Л. А. Пісоцька ${ }^{1}$, Н. В. Глухова² \\ Національна медична академія післядипломної освіти імені П. Л. Шупика \\ ${ }^{1}$ Державний заклад «Дніпропетровська медична академія МОЗ України» \\ ${ }^{2}$ Національний технічний університет «Дніпровська політехніка»
}

Досліджено методи експрес-діагностики енергоінформаційного статусу будь-якого об'єкта навколишнього середовища. Показано, що ефективними є підходи, засновані на візуалізації газорозрядного світіння навколо об'єктів живої і неживої природи в полі високої напруги, відомі в світі, як ефект Кірліана. В роботі представлені результати експериментальних досліджень із використанням кірліанографії у рішенні завдань медицини, екології, педагогічного процесу.

Ключові слова: прикладна кірліанограсрія, екологія, адаптація, дезадаптація.

\section{MAIN DIRECTIONS OF APPLIED KIRLIANOGRAPHY IN ECOLOGY AND MEDICINE}

\author{
O. P. Mintser, L. A. Pisotska ${ }^{1}$, N. V. Glukhova ${ }^{2}$ \\ Shupyk National Medical Academy of Postgraduate Education \\ ${ }^{1}$ State Institution «Dnipropetrovsk Medical Academy of the Ministry of Health of Ukraine» \\ ${ }^{2}$ National Technical University «Dnipro Polytechnic»
}

\begin{abstract}
Background. The methods of express diagnostics of the energy-informational status of any environmental object are investigated. It is shown that approaches based on visualization of a gas-discharge glow around objects of animate and inanimate nature in a high-voltage field, known in the world as the Kirlian effect, are effective.

Materials and methods. Results. The paper presents the results of experimental studies using kirlianography in solving problems of medicine, ecology, and the pedagogical process. To present the results of experimental studies using kirlianography in solving problems of medicine and ecology.

Conclusion. The advantage of kirliography as a bioenergy-informational, innovative method is its high sensitivity and the ability to register nonspecific changes in the body at the level of pre-illness, early detection of electro physical disturbances in biosphere objects with a negative impact on environmental factors, rapid assessment of the state of the energyinformational component of water and biological fluids, determining their bioactivity.
\end{abstract}

Key words: applied Kirlian, ecology, adaptation, desadaptation.

\section{ОСНОВНЫЕ НАПРАВЛЕНИЯ ПРИКЛАДНОЙ КИРЛИАНОГРАФИИ В ЭКОЛОГИИ И МЕДИЦИНЕ}

\author{
О. П. Минцер, Л. А. Песоцкаяㄹ, Н. В. Глухова² \\ Национальная медицинская академия последипломного образования имени П. Л. Шупика

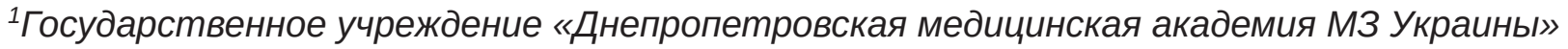 \\ ${ }^{2}$ Национальный технический университет «Днепровская политехника»
}

\begin{abstract}
Исследованы методы экспресс-диагностики энергоинформационного статуса любого объекта окружающей среды. Показано, что эфффективными являются подходы, основанные на визуализации газоразрядного свечения вокруг объектов живой и неживой природы в поле высокого напряжения, известные в мире, как эффект Кирлиана. В работе представлены результаты экспериментальных исследований с использованием кирлианограсрии в решении задач медицины, экологии, педагогического процесса.
\end{abstract}

Ключевые слова: прикладная кирлианография, экология, адаптация, дезадаптация. 
Вступление. Экология человека - неизбежное направление в безопасности современного мира. Целью является гармоничное сочетание удовлетворения материальных потребностей человека с соблюдением нравственно-этических основ. Этим обращается основное внимание на совершенствование личности, как источника всех изменений в мире, согласно учению академика В. И. Вернадского о био- и ноосфере [2]. Последующие экспериментальные исследования А. Гурвича, Н. П. Гаряева, В. П. Казначеева [4, 5, 6, 14] дают представление о внешнем информационном поле, как организующем начале физического и эволюционного развития человека и общества. Физическое здоровье человека можно оценить посредством энергоинформационных полевых взаимодействий, которые А. Гурвич назвал биополями. При этом считается, что они связаны с эмоционально-ментальными духовным состоянием личности, а дисгармония в энергоинформационных взаимодействиях — основа формирования патологических процессов и является причиной прогрессирующих сегодня во всех странах психосоматических заболеваний $[7,41]$.

По аналогии, дезадаптация к условиям окружающей среды любых живых объектов начинается с дисгармонии на уровне энергоинформационных взаимосвязей. Выявление их на полевом уровне является индикатором экологического неблагополучия биокосных и косных тел биосферы в совокупности. Современные открытия в медицине свидетельствуют о наличии электромагнитной составляющей в организме человека, морфологически связанной с древней сосудистой системой, которая обеспечивает полевые взаимодействия с внешней средой [42].

Влияние повреждающих эффектов неоднозначно для живых систем и зависит от внутренних резервов адаптации к ним, в свою очередь, обусловленные функциональным состоянием регуляторных систем, обеспечивающих внутренний гомеостаз организма. Нормальное функционирование их на биохимическом уровне определяет сохранение энергоинформационного гомеостаза и наоборот [1]. П. Мандел экспериментально с использованием метода энергодиагностики по терминальным точкам установил наличие колебательного контура между энергетическим и физиологическим состоянием клетки [41].

Раннее выявление нарушений энергоинформационного гомеостаза живых и биокосных тел биосферы является архиважным в условиях мировой глобализации, введения искусственного элемента во все сферы жизнедеятельности человека, возрастающего влияния антропогенных факторов на биоту.

Специфическим изменениям любой патологии предшествуют неспецифические, нестойкие, отражающие колебательный характер биохимических реакций систем адаптации. Выявление их представляет собой донозологическую диагностику [15]. Биофизический уровень полевых взаимодействий еще более нестабилен. Тем не менее, повторяющиеся изменения в нем увеличивают риск патологических изменений в молекулярных клеточных процессах с формированием патологии.

Поэтому актуальным является разработка методов для экспресс выявления проблем энергоинформационного статуса любого объекта окружающей среды, т. к. все они определяют жизнь на планете.

Такими возможностями обладают методы, основанные на визуализации газоразрядного свечения вокруг объектов живой и неживой природы в поле высокого напряжения, что известно во всем мире, как эффект Кирлиана [16]. Сегодня кирлиановская фотография с различными модификациями получила развитие во многих странах мира $[18,40]$.

Цель работы: представить результаты экспериментальных исследований с использованием кирлианографии в решении задач медицины и экологии.

Материал и методы исследования. Исследования проводили на экспериментальном приборе «РЕК-1», разработанном УкрНИИ технологий машиностроения (г. Днепр) с визуализацией кирлиановского газоразрядного (ГР) свечения вокруг пальцев рук на рентгеновской пленке и цветном фотоматериале (рис. 1а). Исследование жидкофазных объектов проводили на дополнительно разработанной Национальным техническим университетом «Днепровская политехника» (ранее - Национальный горный университет) приставке (рис. 1б) [27].

Фотографировали пальцы рук у лиц исследуемых групп, образцы воды из различных источников и другие жидкофазные объекты, минералы, растения. В качестве оценочных критериев при интерпретации изображений короны свечения вокруг пальцев рук использовали как диагностические критерии, предложенные П. Манделом [41], так и оригинальные показатели. 

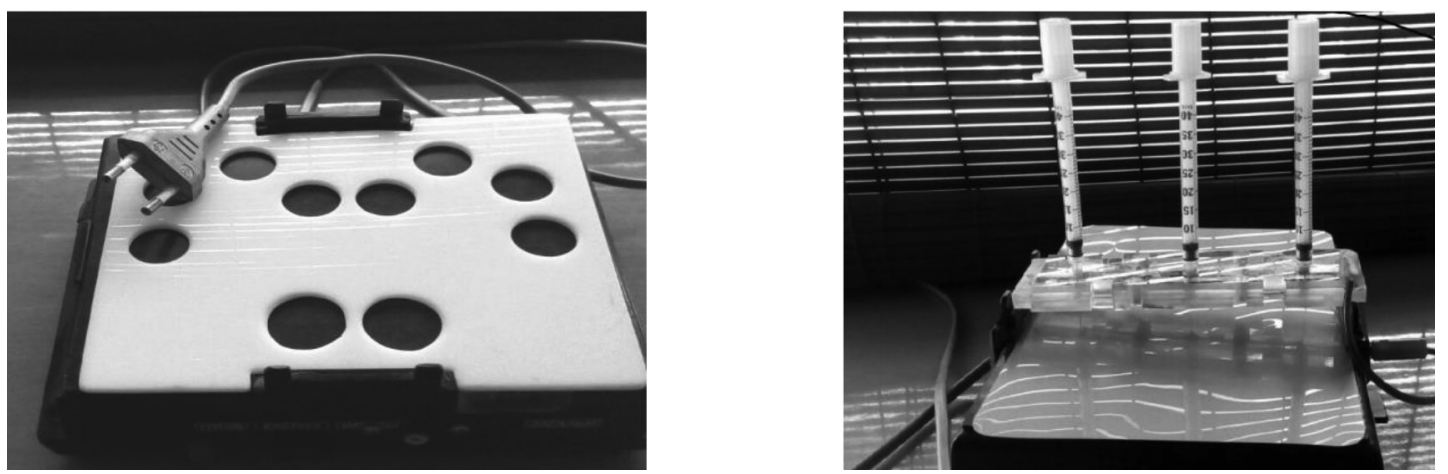

Рис. 1. Фото прибора для кирлианографиечских исследований

Для автоматизированного анализа типов свечения кирлиановского изображения на фотоматериале, отражающих этапы формирования патологического процесса, разработали специализированное программное обеспечение.

Результаты и их обсуждение. В норме корона свечения вокруг пальцев конечностей представлена внутренним сплошным, средним стримерным и наружным люминесцентным слоями. При формирующейся патологии в короне появляются выпадения стримеров (эндокринный тип

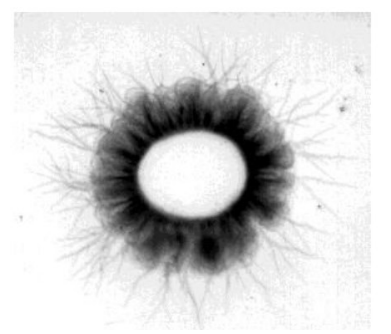

Рис. 2. Нормальный тип свечения

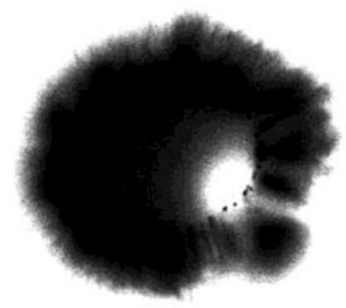

свечения по П. Манделу), отражающие дисфункцию регуляторных систем на уровне предболезни. При ее прогрессии в короне излучений появляется неравномерность стримеров на всех пальцах рук, что соответствует развитию астенизации, хронической усталости организма со снижением иммунологической реактивности к неблагоприятным факторам. Возможно формирование острого срыва адаптационных систем, стресса. В последнем случае в короне свечения выпадения стримеров распространяются на все три ее слоя (рис. 2-4).

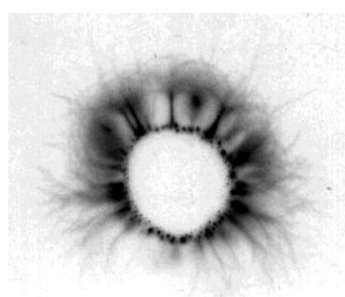

Рис. 3. Эндокринный тип свечения

Рис. 4. Психоэмоциональная лабильность

Переход организма на более низкий уровень адаптационных реакций сопровождается активацией клеточного метаболизма, что клинически проявляется риском воспалительных реакций с интоксикацией. Эти изменения соответствуют электрофизическим состояниям пальцев, которые на кирлиан-фотографии проявляются наличием точечных выпячиваний в короне или вне ее (рис. 5).
Этот тип свечения П. Мандел назвал токсическим. При развитии дистрофических и структурных перестроек в тканях при следующем снижении уровня адаптационных реакций и увеличением анаэробного гликолиза фотонная эмиссия уменьшается, а тепловая увеличивается. Электрофизические изменения проявляются увеличением интенсивности свечения со стертостью рисунка стримеров (рис. 6) [12, 30]. 


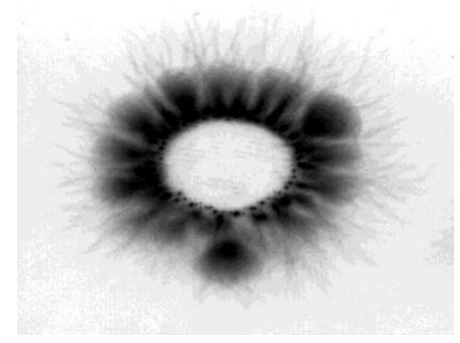

Рис. 5. Токсический тип свечения

Приведем примеры возможного практического применения метода кирлианографии на основании собственных экспериментальных исследований в области различных задач экологии и медицины в течение 20-и лет под руководством профессора О. П. Минцера [3, 10, 11, 17, 22, 29].

Начнем с исследования, проведенного в 2002 году. Обследовали 86 детей в возрасте от 8 до 15 лет из семей ликвидаторов последствий аварии на ЧАЭС или переселенцев с близлежащих территорий Украины до и после санаторно-курортного лечения в санатории «Энергетик» (г. Ялта). На момент обследования дети были практически здоровы. Однако на кирлиан-фотографиях у 99 \% детей были выявлены изменения в короне свечения, характерные для заболеваний в прошлом (хронические заболевания почек, щитовидной железы, желудочно-кишечного тракта, воспалительные заболевания верхних дыхательных путей). У 57 детей, ранее не болевших, выявили дефекты в короне свечения в секторах различных органов. С целью коррекции выявленных изменений была назначена гомеопатическая терапия 31 ребенку на весь период пребывания в санатории (две недели). Контрольной группой были 55 детей без гомеопатической терапии. Сравнительный анализ кирлианограмм после пребывания в санатории выявил большую частоту положительной динамики в энергосостоянии у детей, принимавших гомеопатическую терапию. В частности, наблюдали уменьшение количества детей с энергоблоками в области мочевыделительной системы (35,3 \% и 9,5 \%, соответственно), головы (30,3 \% и 18,4 \%), половой сферы (27,0 \% и 18,9 \%), горло-шеи (31,9 \% и 6,1%), как и признаки интоксикации [43].

В рамках экологических исследований кафедры экологии Национального технического университета «Днепровская политехника» (НТУ «ДП») были обследованы 56 детей дошкольного возраста 4-6 лет из двух экологически неблагоприятных регионов Украины. Результаты кирлианографических

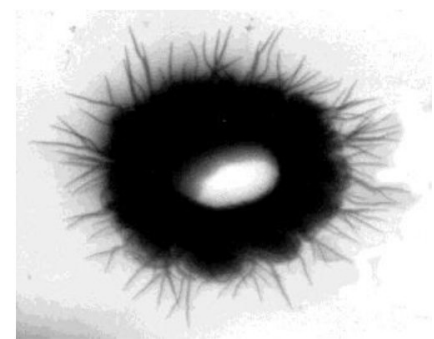

Рис. 6. Дегенеративный тип свечения

исследований сравнивали с результатами цитогенетического анализа по микроядерному тесту буккального эпителия слизистой ротовой полости. По уровню генетических нарушений в соматических клетках дети были разделены на 3 группы. В первую и вторую группу вошли дети из разных районов проживания (14 и 25 детей, соответственно) и одинаковым уровнем цитогенетического повреждения (со значениями микроядерного индекса

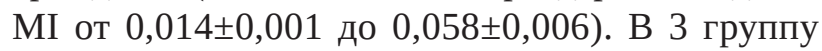
вошли дети из места проживания 1 группы, но с большим повреждающим уровнем клеток по

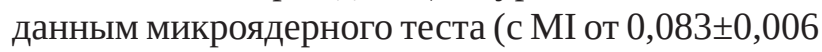

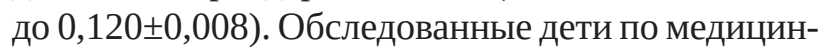
ской документации были практически здоровы. Данные кирлианографического обследования представлены в табл. 1.

Из представленных данных у половины детей всех групп имеются признаки эмоциональной лабильности, астенизации. При сравнении 1 и 2 групп детей из разных мест проживания, одинаковых по клеточному уровню цитогенетического повреждения, во 2 группе обнаружили статистически достоверное увеличение количества детей с интоксикацией как эндо-, так и экзогенной, а также локальной в определенных зонах органов, с признаками дегенеративного типа свечения. Эти признаки свидетельствует о более активных компенсаторных метаболических реакциях адаптации у них по сравнению с детьми 1 группы, с возможными острыми клиническими проявлениями, а также о большей вероятности формирования у них хронической патологии. Данные кирлианографии у этих детей статистически не отличались от детей более тяжелой по уровню цитогенетических повреждений 3 группы, что свидетельствует о лучшей адаптации последних к неблагоприятным факторам.

Таким образом, изменения на кирлианограммах фиксируются до появления повреждающих структурных изменений в ядрах клеток. В то же время, при наличии последних, дефекты в короне 


\section{Результаты кирлианографии у детей из разных регионов (интоксикация)}

\begin{tabular}{|c|c|c|c|c|c|c|c|c|c|c|c|}
\hline \multirow{3}{*}{ Группы } & \multicolumn{11}{|c|}{ Кирлиан признаки } \\
\hline & \multirow[t]{2}{*}{ ЭЛ } & \multirow{2}{*}{$\begin{array}{c}\text { Асте- } \\
\text { низа- } \\
\text { ция }\end{array}$} & \multirow{2}{*}{$\begin{array}{c}\text { Эндо- } \\
\text { генная }\end{array}$} & \multicolumn{7}{|c|}{ Интоксикация } & \multirow{2}{*}{$\begin{array}{c}\text { Дегене- } \\
\text { ративный } \\
\text { тип } \\
\text { излучения }\end{array}$} \\
\hline & & & & $\begin{array}{l}\text { Эндо- } \\
\text { генная }\end{array}$ & ЛГК & $\begin{array}{c}\text { Пря- } \\
\text { мая }\end{array}$ & MBC & ЖВС & $\begin{array}{c}\text { Поло- } \\
\text { вая } \\
\text { систе- } \\
\text { ма }\end{array}$ & $\begin{array}{c}\text { Респи- } \\
\text { ратор- } \\
\text { ная }\end{array}$ & \\
\hline 1 группа & 47 & 47 & 35 & 6 & 53 & 12 & 18 & 65 & 12 & 12 & 0 \\
\hline 2 группа & 52 & 60 & 80 & 40 & 64 & 44 & 44 & 52 & 60 & 56 & 36 \\
\hline 3 группа & 50 & 57 & 50 & 43 & 71 & 29 & 36 & 57 & 43 & 29 & 36 \\
\hline $\begin{array}{c}1 \text { гр. - } \\
2 \text { гр. }\end{array}$ & $\diamond$ & $\diamond$ & $*$ & $*$ & $\diamond$ & $*$ & $\diamond$ & $\diamond$ & $*$ & $*$ & $*$ \\
\hline $\begin{array}{c}2 \text { гр. - } \\
3 \text { гр. }\end{array}$ & $\diamond$ & $\diamond$ & $\diamond$ & $\diamond$ & $\diamond$ & $\diamond$ & $\diamond$ & $\diamond$ & $\diamond$ & $\nabla$ & $\nabla$ \\
\hline $\begin{array}{c}1 \text { гр. - } \\
3 \text { гр. }\end{array}$ & $\diamond$ & $\diamond$ & $\diamond$ & $*$ & $\diamond$ & $\diamond$ & $\diamond$ & $\diamond$ & $*$ & $\diamond$ & * \\
\hline
\end{tabular}

Примечание: ЭЛ - эмоциональная неуравновешенность; ЛГК - лимфоглоточное кольцо; МВС мочевыделительная система; ЖВС - желчевыделительная система; * - разница между показателями статистически достоверна; $\diamond$ - разница между показателями статистически недостоверна

свечения отражают состояние адаптации организма к действию повреждающих факторов [13, 35].

Кирлиановское свечение пальцев рук отражает, как физиологические рефлекторные реакции организма, так и состояние ментально-духовной и психической сфер человека с различными механизмами энергетической активности [25]. Далее на рисунках представлены примеры гистограмм яркости короны свечения вокруг пальцев с градацией, составленной по трем основным цветам, у учащихся в состоянии творческой активности, на факультативном занятии и в состоянии эмоционального спокойствия (рис. 7). С использованием цветной фотопленки по сравнению с известными стандартными методами были выявлены признаки различного функционального состояния детей препубертатного возраста [36, 37].

Метод кирлианофотографии пальцев рук широко использовали для определения типа мышления учащихся, их потенциала, что необходимо учитывать для адекватного изложения учебного материала в конкретных учебных группах для оптимизации его усвоения [24].

Метод классической кирлианографии использовали для экспресс-диагностики состояния здоровья работников на промышленных предприятиях во время профосмотров, что позволило разработать критерии оценки степени неблагоприятного воздействия на организм внешней среды, в том числе условий труда. Выявление дефектов в короне свечения превышало фактическое число проявившейся клинически заболеваемости со стороны органов респираторной сферы на $30 \%$, что было резервом для ее снижения при проведении профилактического оздоровления фито- и гомеопатическими препаратами в рамках программ горисполкома г. Днепропетровска по развитию не медикаментозных методов оздоровления [23].

В частности, было обследовано 250 человек. Частота встречаемости признаков интоксикации у рабочих цехов была в 2 раза чаще, чем у сотрудников заводоуправления, научного подразделения завода, хотя и у них она была достаточно высокой (84,2 \%, 48,4 \%, 48,8 \% соответственно). У работников заводоуправления чаще были признаки эмоциональной неуравновешенности, формирования гастроэнтерологической патологии. У работников научного труда чаще наблюдали дегенеративный тип свечения в области сосудов головы, свидетельствующий о тенденции к появлению сосудистой патологии [10]. В дальнейшем были проведены целевые стандартные методы медицинской диагностики, при необходимости медикаментозное лечение. Оздоравливающее 
Picture

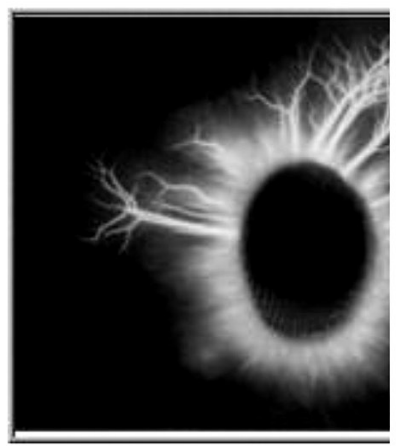

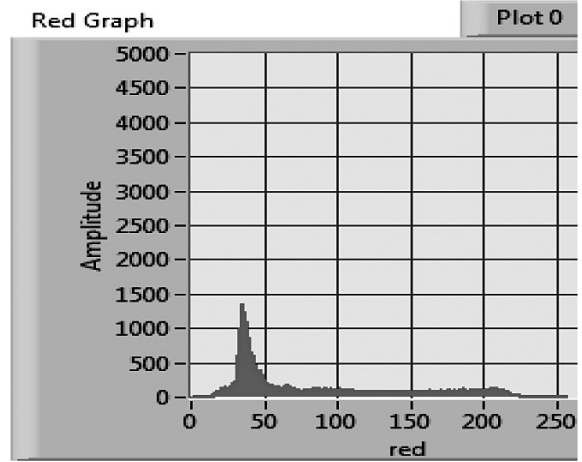

max value RED maxvalue GREEN max

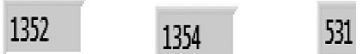

max index RED maxindex GREEN max

35

$36 \quad 22$
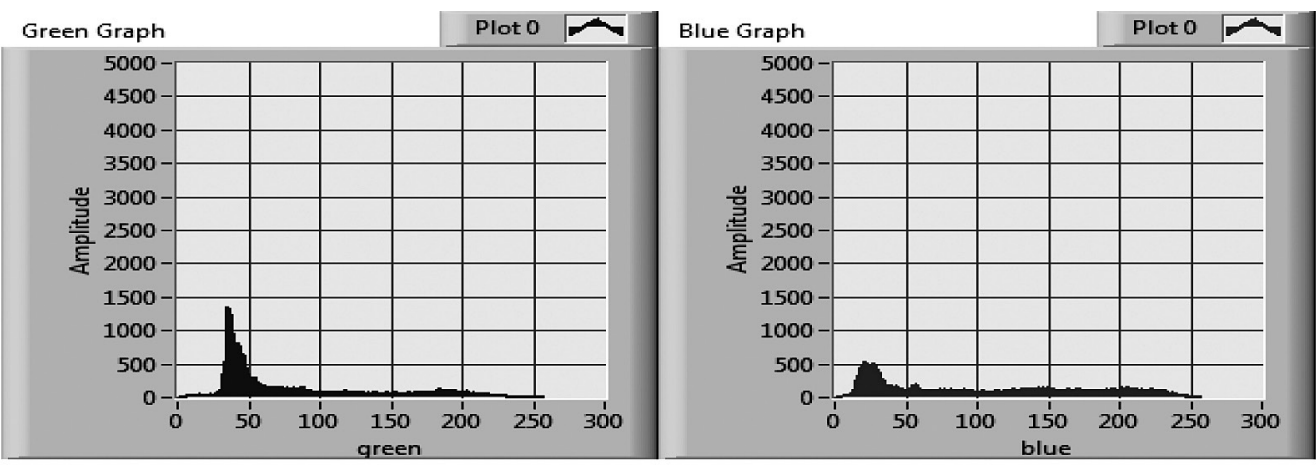

а) Кирлианограмма пальца при ментально-духовной активности
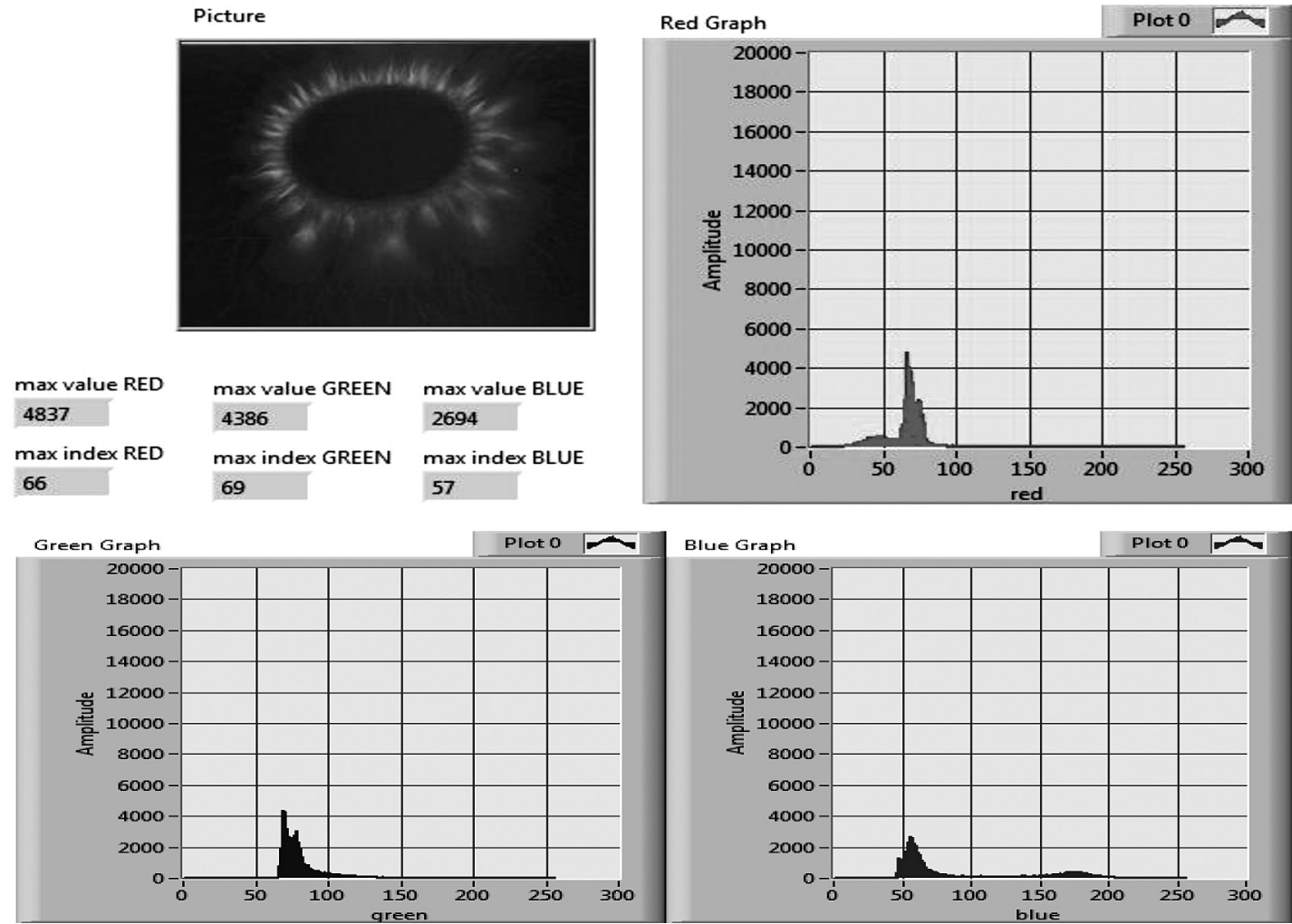

б) Кирлианограмма пальца человека в состоянии покоя

Рис. 7. Примеры кирлиановского свечения на цветной фотопленке в различных психоэмоциональных состояниях учащегося 
влияние на биоэнергетику обследованных лиц оказывало пребывание в шунгитовой и монтмориллонитовой комнатах [21].

Обследуя детей и взрослых, находящихся в одном и том же промышленном районе, в динамике по годам методом кирлианографии выявили соответствие изменений в состоянии их здоровья изменениям санитарно-гигиенических характеристик атмосферы и водных источников в районе
[3]. Таким образом, состояние биоэнергетики у населения в определенном регионе является индикатором состояния экологической ситуации в нем.

Биоиндикатором ее являются и растения. Нами получены кирлиановские фотографии (ки- фото) различных частей растений на рентгеновской пленке. Они визуализируют электрофизиологическое состояние и структуру растений (рис. 7, 8).

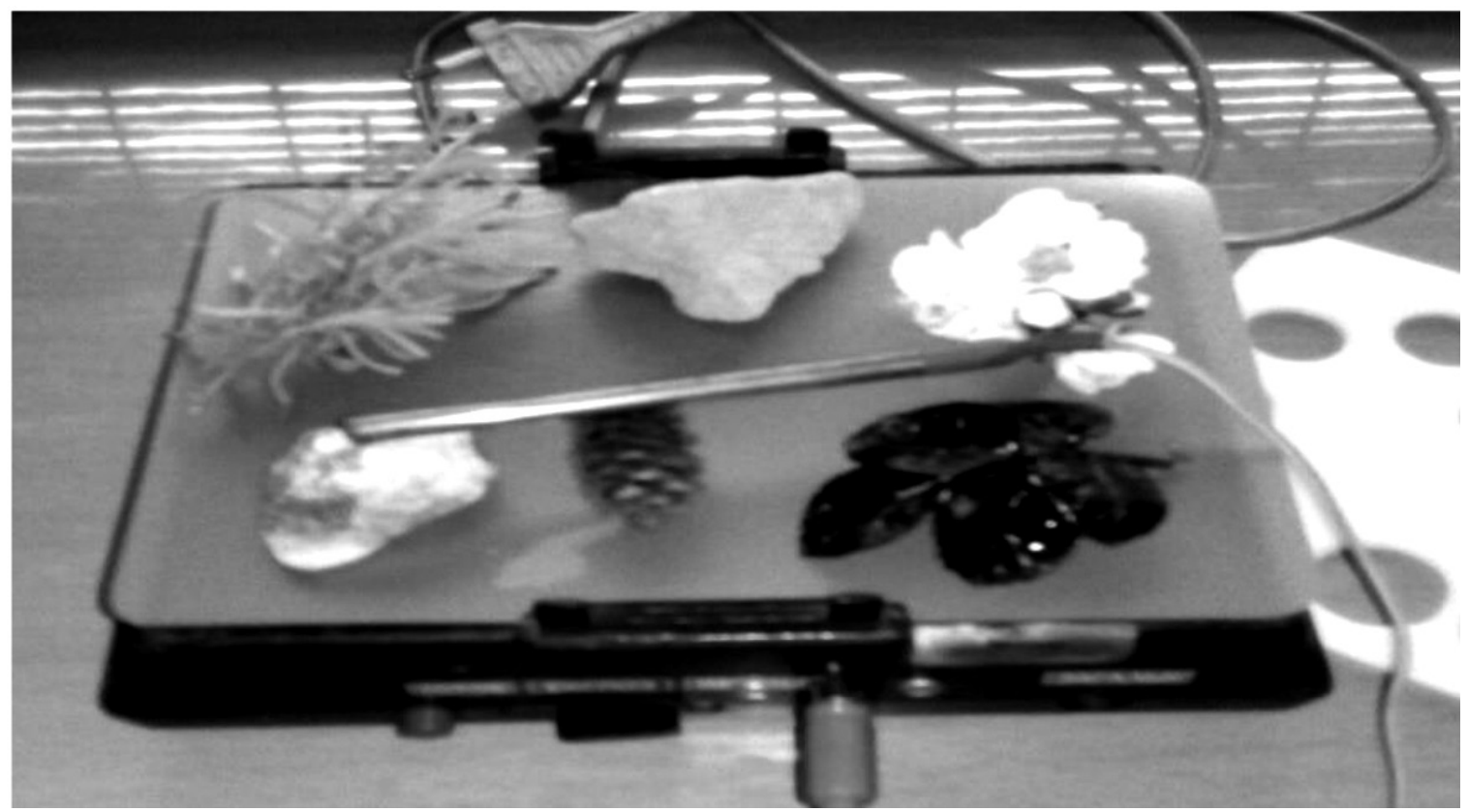

Рис. 7. Фотографирование частей растений

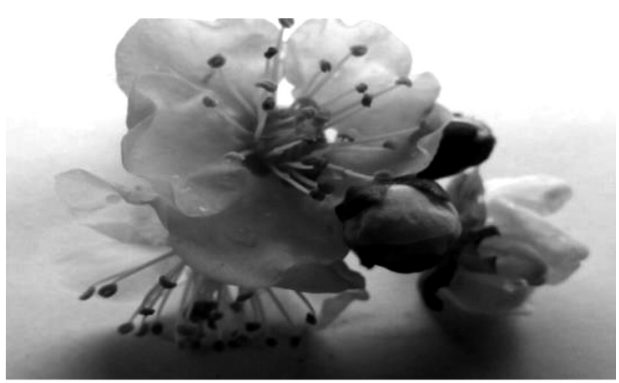

Фото почки и цветка абрикосы

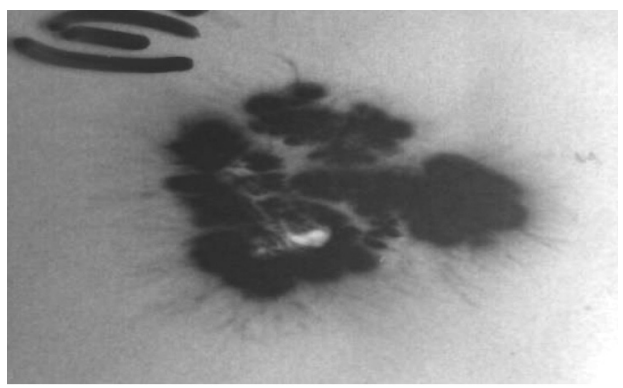

Ки-фото почки абрикоса

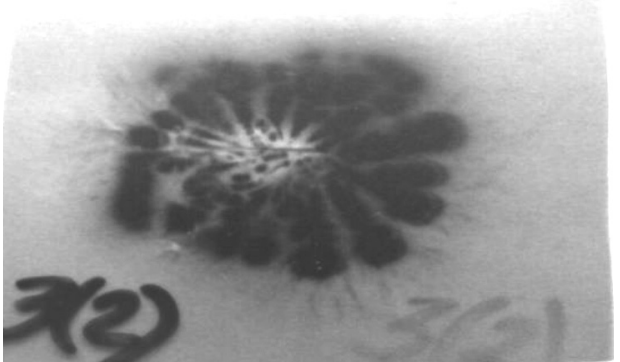

Ки-фото цветка абрикосы

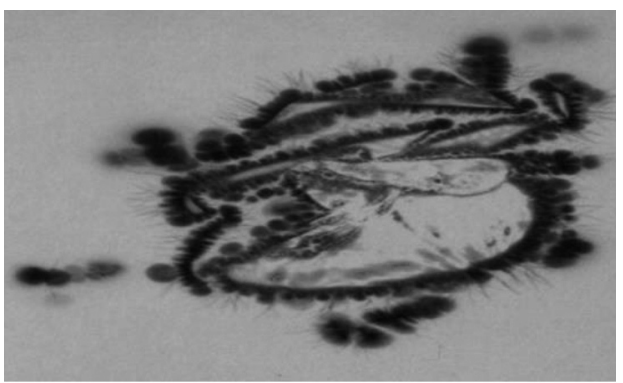

Ки-фото цветка розы 


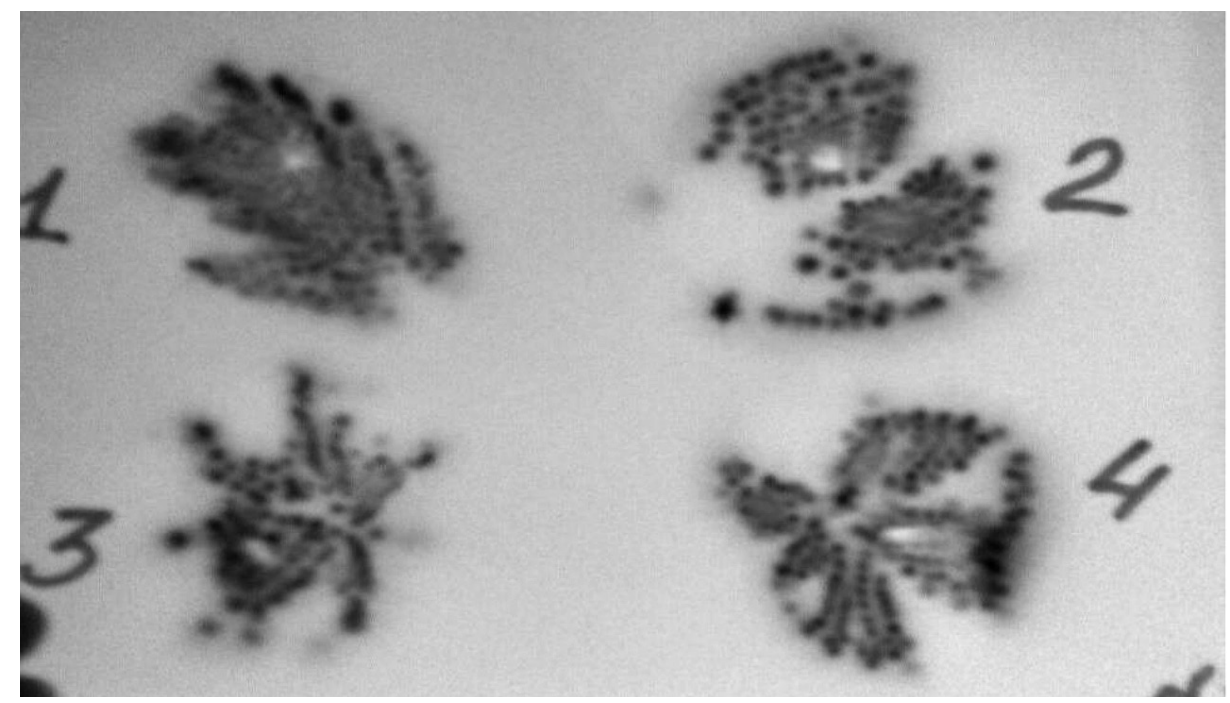

Ки-фото листьев: 1 - мака, 2 - щавеля, 3 - смородины, 4 - земляники

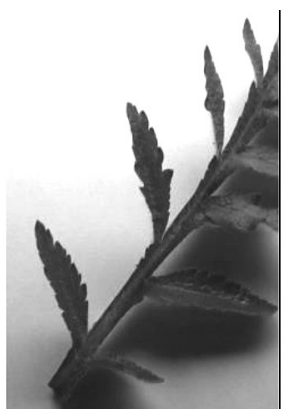

Лист мака

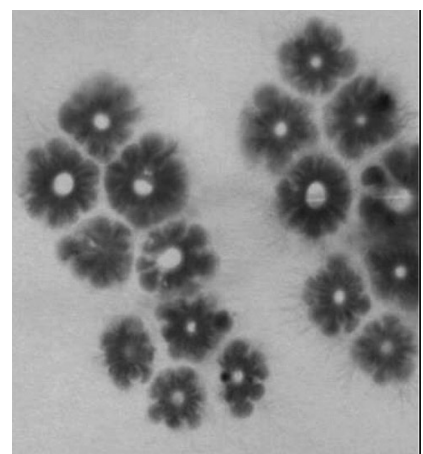

Плоды смородины

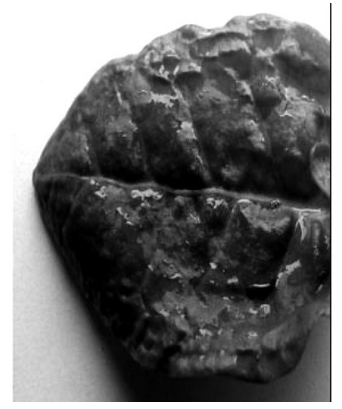

Лист щавеля

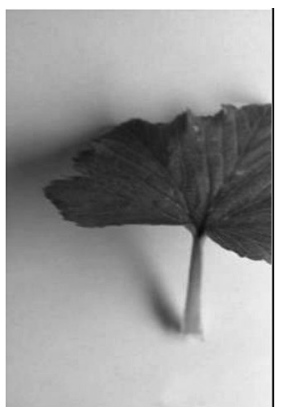

Лист смородины

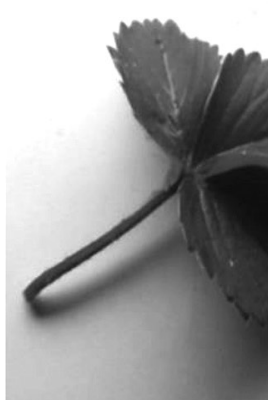

Лист земляники

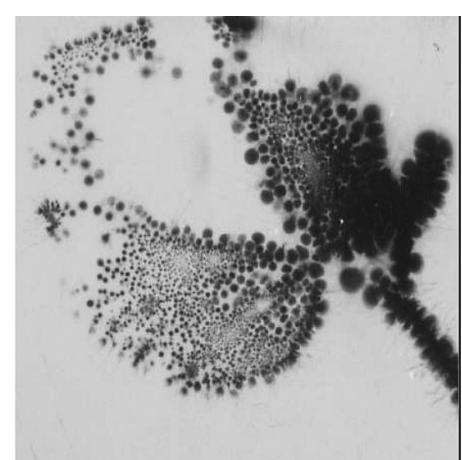

Лист каштана на пленке Кодак

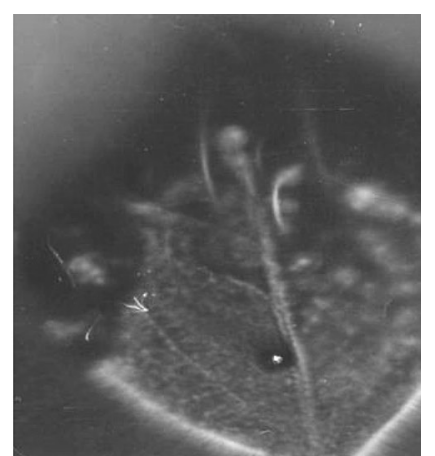

Листья с нарушенной структурой

Рис. 8. Фотографии и кирлиановские фотографии разных частей растений

Намиполучена кирлиановская фотография только что сорванного листа хлорофитуса без видимых внешних повреждений с незначительно сниженной яркостью окраски. На снимке короны свечения визуализировалось образование возле поверхности листа с ееповреждением, что неизбежно привело к гибели листа (рис. 9).

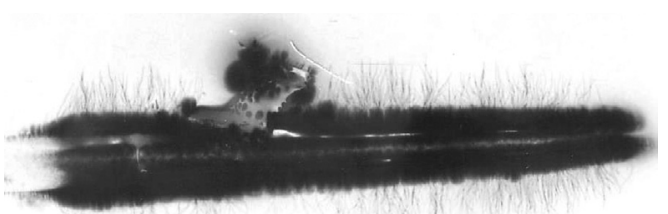

Рис. 9. Кирлианофотография электрофизиологического повреждения листочка хлорофитуса без видимых внешних признаков 
Таким образом, кирлианофотография выявила электрофизиологические нарушения растения, недоступным обычному зрению.

K объектам биосферы, имеющим важное значение для сохранения здоровья населения, относятся водные бассейны. Результаты исследований свечения разных проб воды позволили разработать критерии степени ее биодоступности и предложить полезную модель оценивания ее энергетического состояния, дополняющую принятые ГОСТы.

Свободная, несвязанная в ассоциаты вода легко ионизируется при внешнем источнике напряжения, давая интенсивное свечение короны вокруг капли за счет активных химических реакций с реактивом пленки, испусканием фотонов. Параметры ГРсвечения определяются эмиссионной активностью поверхностного слоя жидкости, которая зависит от наличия поверхностно-активных валентностей. Очевидно, что это свойство определяется структурой поверхностных кластеров [19].

Припреобладании в образцесвободной воды физические параметры ее замеров (электропроводность, растворимость примесей, редокс-потенциал) будут высокими и будут согласовываться между собой. В поляризованном свете визуализируется фрактальная структура воды и выявляется анизотропия, присущая всему живому, проявляющаяся в состояниях фазовых переходов [20].

Иная, чем ионная, проводимость в воде связана с наличием в жидкой части воды областей, организованных в когерентные домены (КД). Надмолекулярные водные агрегаты большое пространство для хранения квазисвободных электронов. Слабоструктурированные части воды с высокой энтропией, используя энергию окружающей среды, преобразуют воду в высокоструктурированную с высокой энергетикой и низкой энтропией. В высокоструктурированной воде внешнее возмущение, которое меньше, чем величина энергетического зазора, не может быть передано другой индивидуальной молекуле, но запасается КД, как единым целым, давая начало коллективному возбужденному состоянию также когерентному. Спектр изолированной воды (например, вблизи поверхности - так называемая EZвода) практически неограничен. Это означает, что внутри КД возможно запасать огромное количество энергии, которое порождает излучение с частотой, достигающей видимой области и ультрафиолета [39]. Поскольку Ки-свечение относится к ультрафиолетовой части спектра, то его изображение отражает энергетику как свободной, так и воды, связанной с наличием в ней КД.

Результаты регистрации экспериментальных данных кирлиановских изображений образцов воды являются двумерными. С целью синтеза системы автоматической классификации воды была создана база изображений, состоящая из результатов регистрации газоразрядного свечения для нескольких типов воды. На основе экспертной информации в качестве типовых вод были использованы следующие: дистиллированная, водопроводная (в/в), природная вне и с территорий монастырей (монастырская). В качестве эталонного объекта для выполнения сравнительного анализа выбраны образцы дистиллированной воды, которая находится в некогерентном состоянии. Другие типы воды с определенной степенью когерентны.

При построении системы автоматизированной классификации по типам воды в качестве основного способа для сравнения геометрических и фотометрических (т. е. яркостных) характеристик изображений использовалось построение гистограмм. При построении гистограммы изображения в анализе задействуются все пиксели с учетом их яркости свечения. Для повышения достоверности выполняемого анализа в качестве исходных данных были использованы выборки с количеством изображений 800-900 для каждого из типов воды. С целью оптимизации вычислительной процедуры количество столбцов гистограммы составляло 12. Высота каждого столбца гистограммы вычислялась с учетом того, что база данных изображений состояла из выборок, содержащих сотни образцов. В качестве наиболее вероятного значения высоты столбца была использована величина медианы, вычисленная для соответствующей выборки изображений. Дальнейшая процедура классификации базируется на использовании метрики - евклидового расстояния между высотами соответствующих столбцов гистограммы.

В качестве дополнительного критерия для сравнения образцов воды также использовался такой количественный показатель как разницы высот столбцов гистограммы в соседних интервалах. Физический смысл применения данного показателя заключается в возможности отслеживания динамических изменений в показателях яркости от интервала к интервалу гистограммы. На рис. 10 представлены изображения и соответствующие гистограммы яркости пикселей для выбранных нами типовых классов воды. 

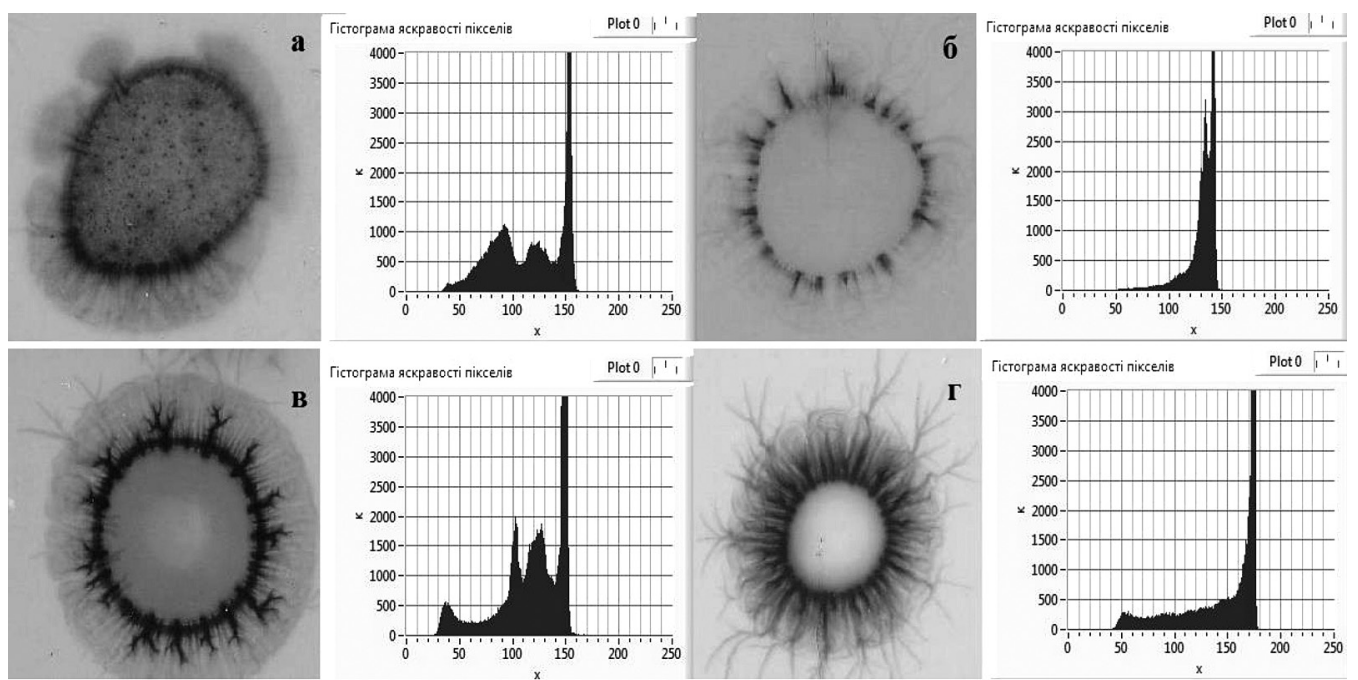

厂

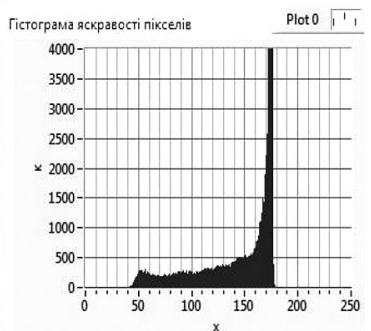

Рис. 10. Анализ изображений воды: а - водопроводная, б - дистиллированная, в - природная, г — из монастырского источника (слева — изображение газоразрядного излучения, зафиксированное на рентгеновской пленке; справа — гистограмма яркости пикселей)
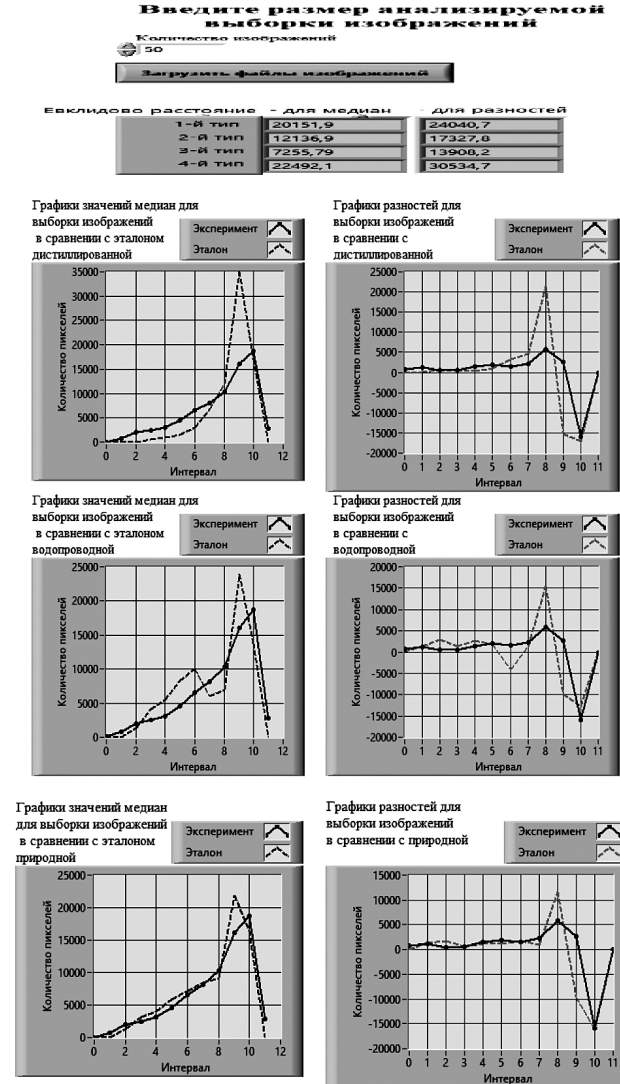

Графихи разностей дли
внборхи изображений
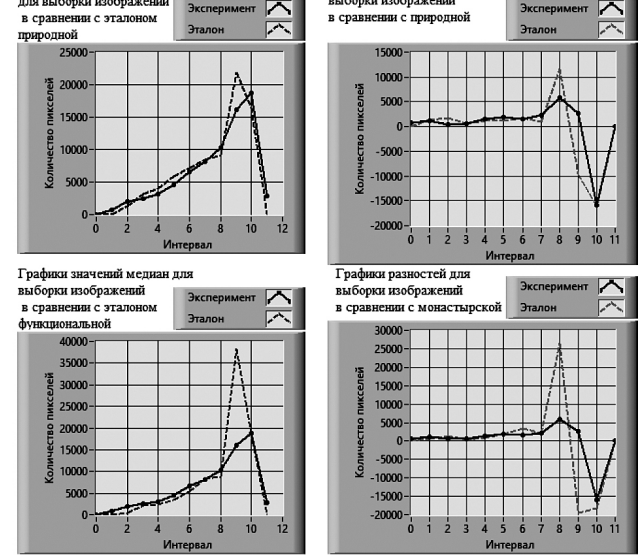

Рис. 11. Пример компьютерного анализа Ки-изображения опытного образца воды по сравнению с типовыми классами 
Максимум амплитуды в гистограмме яркости соответствует фону рентгеновской пленки. Для дистиллированной воды, без примесей, этот пик оказывается единственным экстремумом для графика гистограммы яркости изображения. Она, как было сказано, является наихудшим вариантом с точки зрения ее квантовых и биологических свойств и может использоваться в качестве эталона некогерентной жидкости. Её молекулярная структура построена таким образом, что не может выступать источником свободных носителей заряда. Это проявляется в слабой стримерной короне свечения вокруг капли и наименьшей интенсивностью свечения, по сравнению с другими типами воды.

Более высокими биологическими показателями по критериям ГР свечения обладали образцы вод из природных источников. По результатам проведенных ранее экспериментальных данных, совместно с проф. Куриком М. В., наиболее высоко функциональной по биологическим свойствам оказалась монастырская вода [20].

Интерфейс пользователя прикладного программного обеспечения системы автоматизированной классификации ГР изображений показан на рис. 11.
Наименьшие значения евклидового расстояния указывают на максимальную близость исследуемого образца к одному из типовых классов воды. Графики представляют собой визуальное отображение высот столбцов гистограмм для исследуемого образца воды (сплошная линия) и аналогичные показатели для типовых образцов (пунктирные линии) [8, 9, 26, 28].

Метод кирлианографии на рентгеновской пленке открывает возможности регистрации экологических взаимосвязей в биосфере по квантовым перестройкам в воде, как индикаторе, в том числе, при минимальных внешних воздействиях. Ки-свечения различных структурированных вод обусловлены фотонами разной массы и поэтому по-разному визуализируются на кирлиановской фотографии. Для монастырских вод характерен принципиально отличный от других природных вод кирлиановский рисунок. В нем имеют место люминесценции ярче фона пленки.

В табл. 2 представлены результаты анализа определения типа опытных образцов воды по их энергоинформационным свойствам, согласно экспериментальным критериям кирлиановского свечения типовых классов.

Таблица 2

Результаты определения типа воды опытных образцов по данным кирлианографии из Сходницкого месторождения

\begin{tabular}{|c|c|c|c|c|c|c|c|}
\hline $\begin{array}{c}\text { Образцы } \\
\text { воды }\end{array}$ & 2 & 3 & 4 & 6 & 1 & 5 & 7 \\
\hline $\begin{array}{c}\text { Тип воды } \\
\text { по медиане }\end{array}$ & Пр & Мон & Мон & Мон & Пр & Пр & Мон \\
\hline $\begin{array}{c}\text { Тип воды } \\
\text { по разнице } \\
\text { медиан }\end{array}$ & Пр & Мон & Мон & Мон & Пр & Пр & Мон \\
\hline
\end{tabular}

Примечание: образцы 2, 3, 4, 6 - из скважины; образцы 1, 5, 7 - из бювета, пр. — природная вода, мон. — монастырская вода

Среди образцов из скважины три из четырех по энергоинформационным свойствам соответствовали типу монастырских вод. Образец 2 соответствовал типу природной не монастырской воде. Среди образцов из бювета — все соответствовали природному источнику, один из них был ближе к монастырским водам. Таким образом, разработанный нами способ автоматизированной оценки электрофизиологических свойств воды по ее ГР свечению имеет практическое подтверждение.
Во врачебной практике экспериментально получили кирлианфотографии свечения компонентов крови - клеток и жидкой части ее, мазков крови у пациентов с различной патологией системы кроветворения и у крупного рогатого скота $[31,34]$. Установили признаки риска ее развития, оптимальный выбор препаратов железа при железодефицитной анемии по изменению короны свечения при контакте компонента крови с различными препаратами [32, 33]. Методика апробирована для определения постморбильного 
времени по Ки-свечению жидкости из Ахиллова сухожилия [38].

Выводы. Преимущество кирлианографии, как биоэнергоинформационного, инновационного метода состоит в высокой чувствительности и возможности регистрации неспецифических

\section{Литература.}

1. Белокриницкий В. С. Молекулярная биофизика клетки и здоровье человека. Физиологическая кибернетика / Белокриницкий В. С. // Здоров’я нації і активне довголіття. — 2019. — № 3. - С. 7-18.

2. Вернадский В. И. Геохимия живого вещества. Кн. 1 / Вернадский В. И. - К.: НАН Украины, 2012. -504 c.

3. Возможности использования метода кирлианграфии в системе экологического мониторинга / Л. А. Песоцкая, А. И. Горовая, С. А. Рыженко и др. // Вода: проблемы и решения: матер. VIII научно-практ. конф., г. Днепропетровск, 2008. - С. 70-78.

4. Гавриш О. Г. А. Г. Гурвич: подлинная история биологического поля / Гавриш О. Г. // Химия и жизнь. — 2003. — № 5. - С. 32-37.

5. Биоэнергетика - основа существования живой системы / Галль Л. Н., Галль Н. Р. // Сознание и физическая реальность. — 2012. — Т. 17, № 2. — С. 27-33.

6. Гаряев П. П. Фрактальность ДНК и речи / Гаряев П. П. - Докл. Росс. Ак. Наук, 1994.

7. Гербер Р. Вибрационная медицина / Гербер Р. - М.: София, Гелиос, 2001. - 592 с.

8. Глухова Н. В. Розробка методу експрес-оцінки біологічних властивостей води / Глухова Н. В. // Східно-європейський журнал передових технологій. — 2014. — № 6/5 (72). — С. 18-25.

9. Способ экспресс-оценки жидкофазного объекта / Глухова Н. В., Песоцкая Л. А., Горовая А. И. - Патент на полезную модель. Пат. 86701 Украина: МПК G-1N 21/17; опубл. 10.01.2014.

10. Застосування експрес-методу кірліанграфічної оцінки функціонального стану організму людини для встановлення судинних порушень в області голови та адаптації організму до них: метод. реком. / Є. Л. Мачерет, О. П. Мінцер, Г. М. Чуприна, Л. А. Пісоцька та ін. — К., 2004. — № 275. — 10 с.

11. Застосування методу кірліанграфічної оцінки функціонального стану організму людини в гастроентерологічній практиці: метод. реком. / П. Ф. Кришень, Л. А. Пісоцька, Л. І. Найдьон та ін. - К., 2004. — 11 с.

12. Застосування методу кірліанграфічної оцінки функціонального стану організму людини для встановлення інтоксикації та ступеня адаптації організму до неї: метод. реком. / Пісоцька Л. А., Третяк Н. Н., Видиборець С. В., Мінцер О. П. та ін. - К., 2006. -15 c. изменений в организме на уровне предболезни, раннем определении электрофизических нарушений у объектов биосферы при негативном влиянии на них факторов окружающей среды, экспрессоценке состояния энергоинформационной составляющей воды и биологических жидкостей, определяющих их биоактивность.

13. Застосування методу кірліанграфії для експрес-діагностики ранньої дезадаптації у дітей дошкільного віку до дії несприятливих факторів навколишнього середовища: метод. реком. / О. П. Мінцер, Л. А. Пісоцька, А. І. Горова та ін. - К., 2008. — 20 с.

14. Дистантно-информационные взаимодействия в «пространстве Козырева» / Казначеев В. П., Трофимов А. В. // Физика сознания и жизни, космология и астрофизика. - 2009. - № 1. - С. 5-8.

15. Донозологическая диагностика в практике массовых исследований / Казначеев В. П., Баевский Р. М., Береснева А. П. - Л.: Медицина, 1980. — 208 с.

16. Кирлиан С. Д. Способ получения фотографических снимков различного рода объектов. Авт. свид. № 106401, кл. G03В 41/00; опубл. 01.01.1957.

17. Кирлианография в экологии человека: метод. пособ. по дисц. «Экология человека» / Л. А. Песоцкая, В. М. Лапицкий; под общ. ред. М. В. Курика. - Днепропетровск: Национальный горный университет, 2011. - 45 с.

18. Метод Кирлиан / Колтовой Н. А. - Режим доступа: https://koltovoi.nethouse.ru.

19. Исследование стимулированного свечения воды как показатель ее структуризации / Коротков К. Г. // Созн. и физ. реальность. — 2009. — Т. 14, № 10. - С. 40-46.

20. Кирлианография энергоинформационных взаимодействий воды: монографія / Курик М. В., Песоцкая Л. А., Глухова Н. В., Евдокименко Н. М. - Днепропетровск: Литограф, 2015. - 138 с.

21. Релаксаційна кімната / Лапицький В. М., Гончаренко В. І., Пісоцька Л. А. - Патент України на корисну модель № 61914 від 10.08.2011.

22. Спосіб визначення порушень енергоінформаційного гомеостазу людини / Мінцер О. П., Пісоцька Л. А., Глухова Н. В. - Патент України на корисну модель № 100867; опублік. 25.10.2016. — Бюл. № 20.

23. Використання методу кірліанграфії для експресоцінки функціонального стану організму людини на промислових підприємствах: метод. реком. / Минцер О. П., Горова А. І., Песоцкая Л. А. та ін. K., 2006. - 12 c.

24. Способ определения степени проявления типа мышления человека. Патент України на винахід / Песоцкая Л. А., Глухова Н. В., Третяк Т. О. - Пат. 116702 Украина: МПК А61В 5/05, А61В 5/16; опубл. 25.04.2018. — Бюл. № 8. - 3 с. 
25. Спосіб оцінки рівня рефлекторної активності організму людини / Пісоцька Л. А., Мінцер О. П., Глухова Н. В. та ін. - Патент України на корисну модель № 135618; опублік. 10.07.2019. — Бюл. № 13.

26. Способ оценки биологической активности воды / Песоцкая Л. А., Глухова Н. В. - Патент Украині на полезную модель № 91003: МПК G01N 21/00; опубл. 25.06.2014. — Бюл. № 12.

27. Устройство для регистрации изображения Кирлиансвечения биологических объектов / Песоцкая Л. А., Минцер О. П., Глухова Н. В. - Патент Украины на полезную модель № 100879 от 10.08.2015. — Бюл. № $15 .-3$ с.

28. Способ определения степени когерентности состояния воды / Песоцкая Л. А., Минцер О. П., Глухова Н. В. - Патент Украины на изобретение № 112809; опубл. 25.10.2016. — Бюл. № 20.

29. Способ определения типа энергоинформационной активности организма человека / Песоцкая Л. А., Глухова Н. В. - Патент Украины на полезную модель № 117088: МПК А61В 5/05; опубл. 12.06.2017. — Бюл. № 11. - 4 с.

30. Экспресс-диагностика адаптации организма к неблагоприятным факторам окружающей среды / Песоцкая Л. А., Горовая А. И., Лапицкий В. Н. и др. // Вісник проблем біології і медицини. - 2007. Вип. 1. - С. 62-66.

31. Спосіб діагностики захворювань крові / Пісоцька Л. А., Глухова Н. В. - Патент України на корисну модель № 82295 від 25.07.2013.

32. Спосіб оцінки токсичного впливу лікарського препарату на організм людини / Пісоцька Л.А., Мінцер О.П., Глухова Н.В. та ін. - Патент на корисну модель № 125348; опублік. 10.05.2018. — Бюл. № 9.

33. Спосіб індивідуального підбору лікарських препаратів при лікуванні залізодефіцитних анемій / Пісоцька Л. А., Мінцер О. П., Глухова Н. В., Кочкарова Я. Д. - Патент на корисну модель № 126352; опублік. 11.06.2018. — Бюл. № 11.

34. Спосіб діагностики лейкозу великої рогатої худоби / Пісоцька Л. А., Курик М. В., Минцер О. П. та ін. - Патент України на корисну модель № 83080 від 25.09.2013.

35. Способ прогнозирования ранней дезадаптации у детей дошкольного возраста / Песоцкая Л. А., Горовая А. И., Рукавишникова Д. К. та ін. - Патент Украины на полезную модель № 19465 от 15.12.2006. — Бюл. № 12.

36. Спосіб оцінки імунного стану організму дітей препубертатного віку / Пісоцька Л. А., Рукавишникова Д. К., Лапицький В. М. та ін. - Патент України на корисну модель № 25154 від 25.07.2007. — Бюл. № 11.

37. Спосіб моніторингу функціонального стану адаптаційних систем організму дітей препубертатного віку / Пісоцька Л. А., Рукавишникова Д. К., Лапицький
В. М. та ін. - Патент України на корисну модель № 28757 від 25.12.2007. — Бюл. № 21.

38. Спосіб дослідження біологічної рідини / Пісоцька Л. А., Мінцер О. П., Повстяний В. А. та ін. - Патент України на корисну модель № 120502: G01N 33/48 (2006.01), G01N 21/00; опублік. 10.11.2017. — Бюл. № 21. — 5 с.

39. Гуидиче Э. Д. Когерентная квантовоэлектродинамическая организация биохимических процессов / Э. Д. Гуидиче // Журнал формирующихся направлений науки. — 2014. — № 4 (2). — С. 92-99.

40. Korotkov K. Energy fields electrophotonic analysis in humans and nature / Korotkov K. - 2014. - 233 p.

41. Mandel P. Energetische Terminalpunkt-Diagnose / Mandel P. — Engan, 1983. - 199 c.

42. Evaluation of the human bioelectromagnetic field in medicine: the development of methodology and prospects are at the present scientific stage / O. P. Minser , M. M. Potiazhenko, G. V. Nevoit // Wiadomości Lekarskie — 2019. — № 5, II. — P. 1117-1121.

43. Human being ecology us impotant factor of society stable development. NATO science programme «From transitional economy to sustainable development» / Pesotskaya L. A., Suhoivanova R. I. — Dnipropetrovsk, 2001. - P. 22-25.

\section{References.}

1. Belokrinickij, V. S. (2019). Molekulyarnaya biofizika kletki i zdorove cheloveka. Fiziologicheskaya kibernetika [Molecular cell biophysics and human health. Physiological cybernetics]. Zdorov'ya naciyi i aktivne dovgolittya (The health of the nation and active longevity), 3, 7-18. [In Russian].

2. Vernadskij, V. I. (2012). Geohimiya zhivogo veshestva. Kn. 1 [Geochemistry of living matter. Book 1]. NAN Ukrainy (National Academy of Sciences of Ukraine), Kyiv. [In Russian].

3. Pesockaya, L. A., Gorovaya, A. I., Ryzhenko, S. A., Lapickij, V. N. et al. (2008). Vozmozhnosti ispolzovaniya metoda kirliangrafii v sisteme ekologicheskogo monitoringa [Possibilities of using the kirliangraphy method in the environmental monitoring system] VIII nauchnoprakticheskaya konferenciya Voda: problemy i resheniya (Scientificpractical conference «Water: problems and solutions»). Dnepropetrovsk, 70-8). [In Russian].

4. Gavrish, O. G. (2003). A. G. Gurvich: podlinnaya istoriya biologicheskogo polya [A. G. Gurvich: the true history of the biological field] Himiya i zhizn (Chemistry and life), 5, 32-7. [In Russian].

5. Gall, L. N., Gall, N. R. (2012). Bioenergetika — osnova sushestvovaniya zhivoj sistemy [Bioenergy is the foundation of a living system]. Soznanie i fizicheskaya realnost (Consciousness and Physical Reality), 17 (2), 27-33. [In Russian].

6. Garyaev, P. P. (1994). Fraktalnost DNK i rechi [DNA and speech fractality]. Dokl. Ross. Ak. Nauk (Report of the Russian Academy of Sciences). [In Russian]. 
7. Gerber, R. (2001). Vibracionnaya medicina [Vibratory medicine]. Moscow, Sofiya, Gelios. [In Russian].

8. Gluhova, N. V. (2014). Rozrobka metodu ekspresocinki biologichnih vlastivostej vodi [Development of a method for rapid assessment of biological properties of water]. Shidno-yevropejskij zhurnal peredovih tehnologij (Eastern European Journal of Advanced Technologies). 6/5 (72), 18-25. [In Ukranian].

9. Gluhova, N. V., Pesockaya, L. A., Gorovaya, A. I. (2014). Sposob ekspress-ocenki zhidkofaznogo obekta [The method of rapid assessment of a liquid-phase object]. Patent na poleznuyu model (Utility Model Patent), Pat. 86701, 10.01.2014. [In Russian].

10. Macheret, Ye. L., Mintser, O. P., Chuprina, G. M., Pisocka, L. A. et al. (2004). Zastosuvannya ekspresmetodu kirliangrafichnoyi ocinki funkcionalnogo stanu organizmu lyudini dlya vstanovlennya sudinnih porushen $\mathrm{v}$ oblasti golovi ta adaptaciyi organizmu do nih [Application of the express method of Kirliangraphic assessment of the functional state of the human body to establish vascular disorders in the head and adaptation of the body to them]. Metodichni rekomendaciyi (Methodical recommendations), 275. [In Ukrainian].

11. Krishen, P. F., Pisocka, L. A., Najdon, L. I. et al. (2004). Zastosuvannya metodu kirliangrafichnoyi ocinki funkcionalnogo stanu organizmu lyudini $\mathrm{v}$ gastroenterologichnij praktici [Application of the method of Kirliangraphical assessment of the functional state of the human body in gastroenterological practice]. Metodichni rekomendaciyi (Methodical recommendations), Kyiv. [In Ukrainian].

12. Pisocka, L. A., Tretyak, N. N., Gajdukova, S. N. et al. (2006). Zastosuvannya metodu kirliangrafichnoyi ocinki funkcionalnogo stanu organizmu lyudini dlya vstanovlennya intoksikaciyi ta stupenya adaptaciyi organizmu do neyi [Application of the method of Kirliangraphical assessment of the functional state of the human body to establish intoxication and the degree of adaptation of the organism to it]. Metodichni rekomendaciyi (Methodical recommendations), Kyiv. [In Ukrainian].

13. Mintser, O. P., Pisocka, L. A., Gorova, A. I. (2008). Zastosuvannya metodu kirliangrafiyi dlya ekspresdiagnostiki rannoyi dezadaptaciyi u ditej doshkilnogo viku do diyi nespriyatlivih faktoriv navkolishnogo seredovisha [Application of the Kirliangraphy method for rapid diagnosis of early maladaptation in preschool children to the action of adverse environmental factors]. Metodichni rekomendaciyi (Methodical recommendations, Kyiv. [In Ukrainian].

14. Kaznacheev, V. P., Trofimov, A. V. (2009). Distantnoinformacionnye vzaimodejstviya v «prostranstve Kozyreva» [Distant informational interactions in the «Kozyrev space»]. Fizika soznaniya $i$ zhizni, kosmologiya i astrofizika (Physics of consciousness and life, cosmology and astrophysics), 1, 5-8. [In Russian].
15. Kaznacheev, V. P., Baevskij, R. M., Beresneva, A. P. (1980). Donozologicheskaya diagnostika v praktike massovyh issledovanij [Prenosological diagnosis in the practice of mass research]. Leningrad: Medicina. [In Russian].

16. Kirlian, S. D. (1957). Sposob polucheniya fotograficheskih snimkov razlichnogo roda obektov [The method of obtaining photographic images of various kinds of objects]. Avt. svid. (Certificate of authorship). [In Russian].

17. Pesockaya, L. A, Lapickij, V. M., Kurik, M. V. (2011). Kirlianografiya v ekologii cheloveka: metodicheskoe posobie po discipline «Ekologiya cheloveka» [Kirlianography in human ecology. The manual on the discipline «Human Ecology»]. Nacionalnyj gornyj universitet (National Mining University), 45, Dnepropetrovsk. [In Russian].

18. Koltovoj, N. A. Metod Kirlian. Retrieved from: https:// koltovoi.nethouse.ruKirlian method. [In Russian].

19. Korotkov, K. G. (2009). Issledovanie stimulirovannogo svecheniya vody kak pokazatel ee strukturizacii [Investigation of the stimulated glow of water as an indicator of its structurization]. Sozn. i fiz. realnost (Consc. and physical reality), 14 (10), 40-6. [In Russian].

20. Kurik, M. V., Pesockaya, L. A., Gluhova, N. V., Evdokimenko, N. M. (2015). Kirlianografiya energoinformacionnyh vzaimodejstvij vody [Kirlianografiya energyinformational interactions of water]. 138, Dnepropetrovsk, Litograf. [In Russian].

21. Lapickij, V. M., Goncharenko, V. I., Pisocka, L. A. (2011). Relaksacijna kimnata [Relaxation kimnata]. Patent Ukrayini na korisnu model № 61914 vid 10.08.2011. [In Ukranian].

22. Mintser, O. P., Pisocka, L. A., Gluhova, N. V. (2016). Sposib viznachennya porushen energo-informacijnogo gomeostazu lyudini [Method for determining violations of human energy_information homeostasis ]. Patent Ukrayini na korisnu model № 100867; opublik. 25.10.2016. Byul. № 20. [In Ukrainian].

23. Mintser, O. P., Gorova, A. I, Pesockaya, L. A. (2006). Vikoristannya metodu kirliangrafiyi dlya ekspres-ocinki funkcionalnogo stanu organizmu lyudini na promislovih pidpriyemstvah: metodychni rekomendatsiyi [The use of the method of Kirliangraphy for rapid assessment of the functional state of the human body in industrial enterprises: ]. Kyiv. [In Ukrainian].

24. Pesockaya, L. A., Gluhova, N. V., Tretyak, T. O. (2018). Sposob opredeleniya stepeni proyavleniya tipa myshleniya cheloveka. [A method of determining the degree of manifestation of the type of human thinking]. Patent Ukrainy na vinahid, 116702; opubl. 25.04.2018, 8, 3. [In Russian].

25. Pisocka, L. A., Mintser, O. P., Gluhova, N. V. et al. (2019). Sposib ocinki rivnya reflektornoyi aktivnosti organizmu lyudini [Method of estimating the level of reflex activity of the human body]. Patent Ukrayini na 
korisnu model № 135618; opublik. 10.07.2019, 13. [In Ukrainian].

26. Pesockaya, L. A., Gluhova, N. V. (2014). Sposob ocenki biologicheskoj aktivnosti vody [Method for estimating biological activity of water]. Patent na poleznuyu model № 91003; opubl. 25.06.2014, 12.

27. Pesockaya, L. A., Mintser, O. P., Gluhova, N. V. (2015). Ustrojstvo dlya registracii izobrazheniya Kirliana-svecheniya biologicheskih obektov [Device for registration of the image of Kirlian-glow of biological objects]. Patent of Ukraine for a useful model № 100879 from 10.08.2015, 15, 3. [In Ukrainian].

28. Pesockaya, L. A., Mintser, O. P., Gluhova, N. V. (2016). Sposob opredeleniya stepeni kogerentnosti sostoyaniya vody [The method of determining the degree of coherence of the state of water]. Patent Ukrainy na izobretenie № 112809; opubl. 25.10.2016, 20. [In Russian].

29. Pesockaya, L. A., Gluhova, N. V. (2017). Sposob opredeleniya tipa energoinformacionnoj aktivnosti organizma cheloveka [The method of determining the type of energy information activity of the human body]. Patent na poleznuyu model № 117088; opubl. 12.06.2017, 11, 4. [In Russuan].

30. Pesockaya, L. A., Gorovaya, A. I., Lapickij, V. N. (2007). Ekspress-diagnostika adaptacii organizma k neblagopriyatnym faktoram okruzhayushej sredy [Express diagnostics of adaptation of an organism to adverse environmental factors]. Visnik problem biologiyi i medicine (Bulletin of problems biology and medicine), 1, 62-6. [In Russian].

31. Pisocka, L. A., Gluhova, N. V. (2013). Sposib diagnostiki zahvoryuvan krovi [Method for diagnosing blood diseases]. Patent Ukrayini na korisnu model № 82295 vid 25.07.2013. [In Ukrainian].

32. Pisocka, L. A., Mintser, O. P., Gluhova, N. V. et al. (2018). Sposib ocinki toksichnogo vplivu likarskogo preparatu na organizm lyudini. [Method for assessing toxic effect of drug on human body]. Patent na korisnu model № 125348; opublik. 10.05.2018. [In Ukrainian].

33. Pisocka, L. A., Mintser, O. P., Gluhova, N. V. et al. (2018). Sposib individualnogo pidboru likarskih preparativ pri likuvanni zalizodeficitnih anemij [Method of individual selection of drugs in the treatment of iron deficiency anemia]. Patent na korisnu model № 126352; opublik. 11.06.2018, 11. [In Ukrainian].

34. Pisocka, L. A., Kurik, M. V., Zaviryuha, A. A., Mintser, O. P., Gluhova, N. V. (2013). Sposib diagnostiki lejkozu velikoyi rogatoyi hudobi [Method for diagnosing bovine leukemia]. Patent Ukrayini na korisnu model № 83080 vid 25.09.2013. [In Ukrainian].

35. Pesockaya, L. A., Gorovaya, A. I., Rukavishnikova, D. K. et al. (2006). Sposob prognozirovaniya rannej dezadaptacii u detej doshkolnogo vozrasta [Method for predicting early maladaptation in preschool children]. Patent Ukrainy na poleznuyu model № 19465 ot 15.12.2006, 12. [In Russian].

36. Pisocka, L. A., Rukavishnikova, D. K., Lapickij, V. M. et al. (2007). Sposib ocinki imunnogo stanu organizmu ditej prepubertatnogo viku [Method for assessing the immune status of the body of prepubertal children]. Patent Ukrayini na korisnu model № 25154 vid 25.07.2007, 11. [In Russian].

37. Pisocka, L. A., Rukavishnikova, D. K., Lapickij, V. M. et al. (2007). Sposib monitoringu funkcionalnogo stanu adaptacijnih sistem organizmu ditej prepubertatnogo viku [Method of monitoring the functional state of adaptive systems of the body of prepubertal children]. Patent Ukrayini na korisnu model № 28757 vid 25.12.2007, 21. [In Ukrainian].

38. Pisocka, L. A., Mintser, O. P., Povstyanij, V. A. et al. (2017). Sposib doslidzhennya biologichnoyi ridini [Biological fluid research method]. Patent Ukrayini na korisnu model № 120502; opublik. 10.11.2017, 21, 5. [In Ukrainian].

39. Guidiche, E. D. (2004). Kogerentnaya kvantovoelektrodinamicheskaya organizaciya biohimicheskih processov [Coherent quantum-electrodynamic organization of biochemical processes]. Zhurnal formiruyushihsya napravlenij nauki (Journal of emerging areas of science), 4 (2), 92-9. [In Russian].

40. Korotkov, K. (2014). Energy fields electrophotonic analysis in humans and nature.

41. Mandel, P. (1983). Energetische TerminalpunktDiagnose. Engan.

42. Mintser, O. P., Potiazhenko, M. M, Nevoit, G. V. (2019). Evaluation of the human bioelectromagnetic field in medicine: the development of methodology and prospects are at the present scientific stage. Wiadomości Lekarskie, 5 (II), 1117-21.

43. Pesotskaya, L. A., Suhoivanova, R. I. (2001). Human being ecology us impotant factor of society stable development. NATO science programme «From transitional economy to sustainable development». Dnipropetrovsk. 